\title{
USP14 wt Allele
}

National Cancer Institute

\section{Source}

National Cancer Institute. USP14 wt Allele. NCI Thesaurus. Code C132091.

Human USP14 wild-type allele is located in the vicinity of 18p11.32 and is approximately $56 \mathrm{~kb}$ in length. This allele, which encodes ubiquitin carboxyl-terminal hydrolase 14 protein, plays a role in the removal of ubiquitin from protein substrates. 